\title{
603 管内走行用磁気アクチュエータの走行特性におよぼす加振力の影響 Electromagnetic Force on Locomotion properties of Magnetic In-Piping Actuator
}

\author{
○渡邊 龍一 (東北学院大学) 泉川 友宏（東北学院大学）正 矢口 博之（東北学院大学）
}

Ryuichi WATANABE, Hiroyuki YAGUCHI

Tohoku Gakuin University, 1-13-1 Tagajo, Miyagi

Key words: magnetic actuator, dc-ac inverter, locomotion principle, resonance drive, inertia force.

\section{1.はじめに}

原子炬，化学プラントライン，医療などの幅広い分野に おいて，管内探索マイクロロボットの要求が高まってきて いる。これら問題の一つとして著者らは，配管の検查やメ ンテナンスを最終目的とした，管内走行用ケーブルレス型 マイクロ磁気アクチュエータ11 を提案している。しかし， 本ケーブルレス型アクチュエータにおいては，走行距離や 推進特性については未だ改善点点も多く, 実用化に向けて 性能の更なる向上が必要となる.

本研究では，ボビン状の形状を有する電磁石を搭載し， 共振エネルギーにより走行可能な内径 $8 \mathrm{~mm}$ の管内走行用 ケーブルレス型磁気アクチュエータを提案している。実験 では，アクチュエータの動力源となる磁気発生力が大とな るように，ボビン形状の検討を行った．さらにアクチュエ 一夕の保持力変化させた場合の走行原理の確立を図った。

\section{2. ケーブルレス型磁気マイクロアクチュエータの構造}

図 1 は内径 $8 \mathrm{~mm}$ の管内を走行可能な磁気アクチュエー タの構造を示したものである．本アクチュエータは，自身 の振動によりボタン電池の直流電圧を交流電圧に自動的に 変換させる DC-AC インバータと図 2 に示すような推進部 とに大別される。推進部は、リング型永久磁石 $\mathrm{A}$ および $\mathrm{B}$, 同一諸元を有する 2 個の並進ばね並びにボビン状電磁石に より構成される. 用いた永久磁石は，両面 2 極着磁リング 型 $\mathrm{NdFeB}$ 磁石で，その寸法はタイプ A については外径 $\Phi$

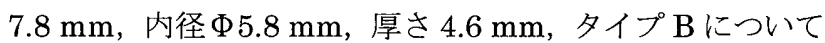
は外径 $\Phi 6.5 \mathrm{~mm}$, 内径 $\Phi 2 \mathrm{~mm}$ ，厚さ $1.5 \mathrm{~mm}$ である. 並 進ばねとしては，ばね定数 $\mathrm{k}=1425 \mathrm{~N} / \mathrm{m}$ ，自由長 $5 \mathrm{~mm}$, 外径 $6 \mathrm{~mm}$ のステンレス鋼製圧縮コイルばねを用いた.

さて図 2 に示すようなボビン状電磁石において, 両端の円 盤状コアの直径は $5.0 \mathrm{~mm}$, 幅は $0.5 \mathrm{~mm}$ であり, 両者を連 結する軟鋼丸棒の直径は $2.5 \mathrm{~mm}$ である．本電磁石には外 径 $0.07 \mathrm{~mm}$ の銅線を 3200 回巻きつけており，その電気抵 抗は $225 \Omega$ ズる.また図1に示すように，アクチュエー タのフレーム両端には 2 枚の柔軟な長方形状の自然ゴム材が

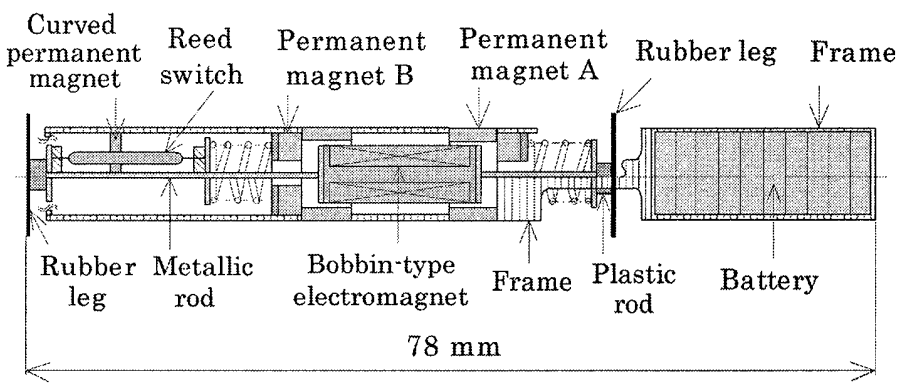

Fig.1 Structure of actuator.

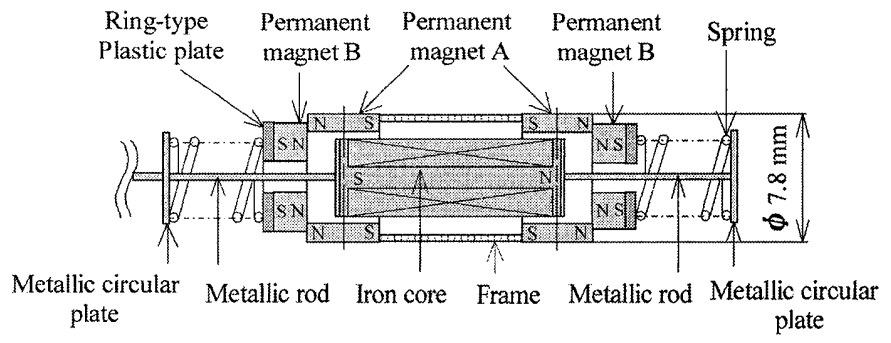

Fig.2 Propulsion module of actuator.

取り付けられている．このゴム材によってアクチュエータは 管内で保持され，推進部において生じる交番的な力を効果的 に一方向運動に変換することが可能である. アクチュエータ の寸法は, ボタン電池搭載時において全長 $78 \mathrm{~mm}$, 外径 $7.8 \mathrm{~mm}$ であり, 総質量はボタン電池 10 個搭載時において $9.7 \mathrm{~g}$ である.

図 3 はボタン電池などの直流電圧を, 振動体が必要とす る交流電圧に変換する, DC-AC インバー夕による自励振回 路の原理を示したものである.これら DC-ACインバー夕は, 磁気感応素子である長さ $10 \mathrm{~mm}$, 外径 $1.8 \mathrm{~mm}$ のリードスイッ チと, アクチュエータ本体に固定された円弧状永久磁石により 構成される. なお，アクチュエータ静止時において，リードス イッチは永久磁石に感応せず，電磁石に電力は供給されない， 電磁石に外部から初期変位を与えると, 結合ロッドに取付け られたリードスイッチは，永久磁石を中心として比較的大き な振幅で振動する。この振幅差によりリードスイッチと永久 


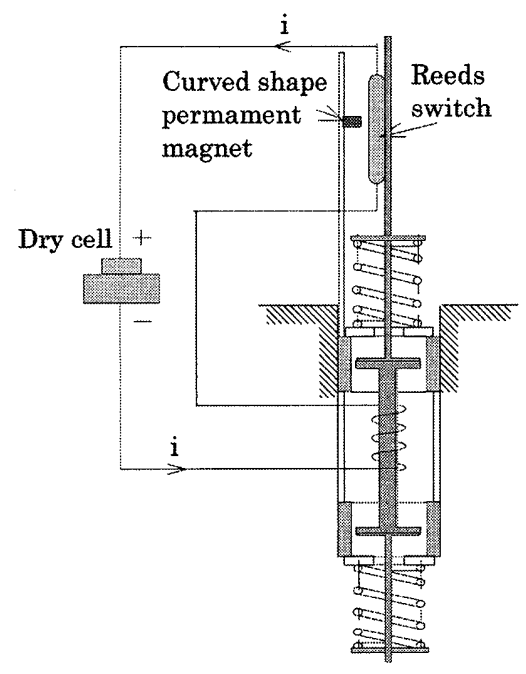

Fig.3 DC-AC inverter.

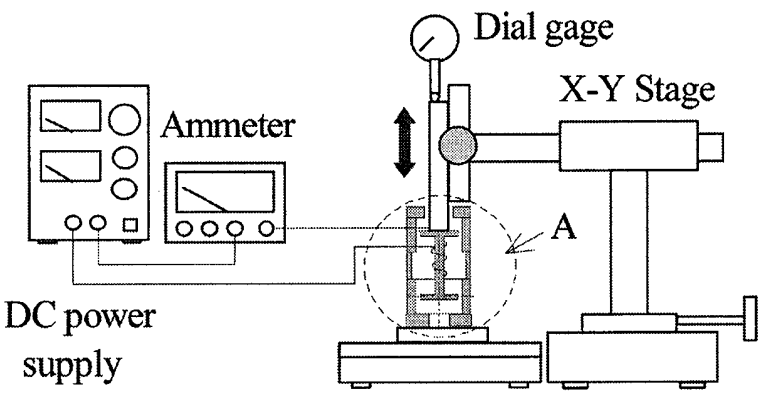

Fig. 4. Experimental apparatus.

磁石との間には，磁界の強弱が発生する。これらを利用して リードスイッチは ON-OFF 動作を行い，電池の直流電圧は 方形波に自動的に変換される.この生成された電圧が，電 磁石に電磁的加振力を与え, アクチュエータは永続的に共 振状態を維持することができる.

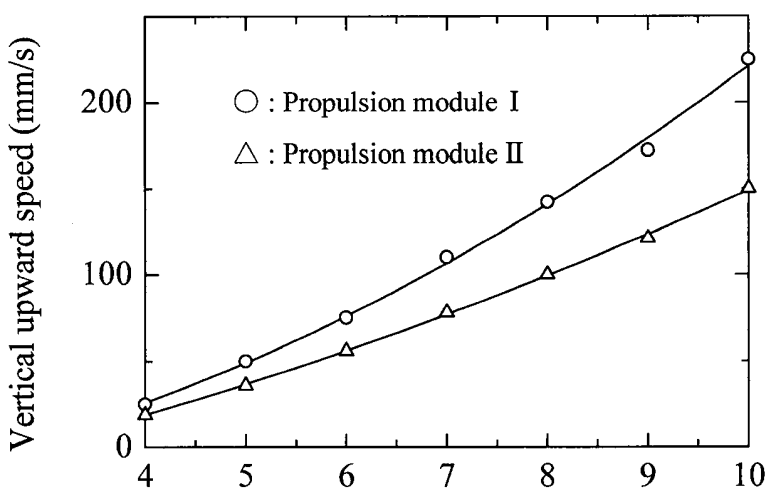

Number of batteries

Fig. 5. Relationship between number of battery and vertical upward speed.
また，図 4 に示すように，入力電流を変化させた場合の推 進部の磁気発生力をフォースゲージを用いて測定した.

さて, 電磁石に入力する電流をパラメータとして, 推進 電流を変化させた場合のアクチュエータの走行速度を測定 し，磁気発生力と走行特性との関係を明らかにした．入力 電流を変化させた場合のアクチュエータの推進特性の変化 を図 5 に示す. 入力電流の増加により推進部の磁気発生力 は増加し, 推進部の振動変位は増加する. この変位の増加 により走行速度は 2 次的に増加することを解明した.また， 本アクチュエータは 4 個の電池でも走行可能であることを 明らかにした。

\section{3. アクチュエータの走行特性}

アクチュエータを駆動する直流電源としては，マクセル 社製 SR626W ボタン型酸化銀電池を用いた。その諸元は， 外形 $6.8 \mathrm{~mm}$, 厚さ $2.6 \mathrm{~mm}$, 質量 $0.4 \mathrm{~g}$, 公称電圧 $1.55 \mathrm{~V}$ である. 図 6 はパイプ傾き角度とアクチュエータの走行速 度との関係を電池の個数をパラメータとして示したもので ある. 図において, $90^{\circ}$ は垂直上昇， $-90^{\circ}$ は垂直下降を意 味している. 図より電池 10 個搭載時, 本アクチュエータの 垂直上昇速度は $225 \mathrm{~mm} / \mathrm{s}$, 水平移動速度は $287 \mathrm{~mm} / \mathrm{s}$ で ある。

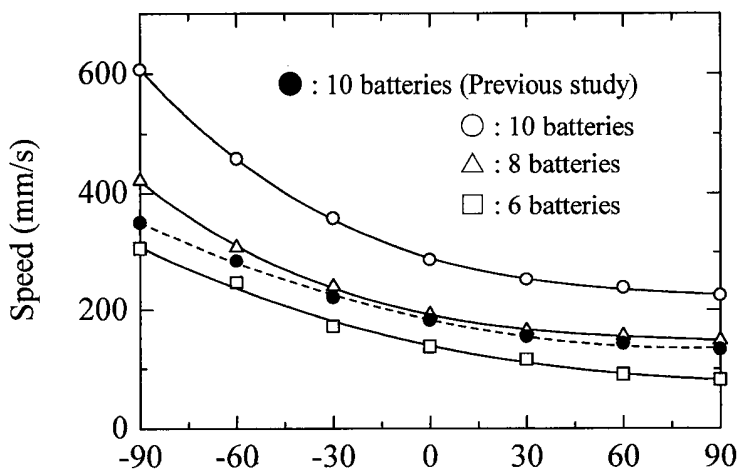

Tilt angle $\alpha(\mathrm{deg}$.

Fig.6 Relationship between angle and speed.

\section{4. まとめ}

新しい電磁石コアを搭載した高推進力発生が可能な管内 走行用ケーブルレス型磁気アクチュエータを試作し，その試 作モデルについて推進性能を検討した。 また, 推進部の磁気 発生力が推進特性と与える影響を明らかにした. ボタン型電 池 10 個搭載時, その垂直上昇速度は $225 \mathrm{~mm} / \mathrm{s}$ であり, $10 \mathrm{~g}$ の負荷質量を搭載しても, $90 \mathrm{~mm} / \mathrm{s}$ の速度で垂直上昇するこ とが確認された。 